\title{
Author Correction: Promoter interactome of human embryonic stem cell-derived cardiomyocytes connects GWAS regions to cardiac gene networks
}

\author{
Mun-Kit Choy (10 ', Biola M. Javierre ${ }^{2,3}$, Simon G. Williams ${ }^{1}$, Stephanie L. Baross ${ }^{1}$, Yingjuan Liu', \\ Steven W. Wingett ${ }^{2}$, Artur Akbarov ${ }^{1}$, Chris Wallace (1) ${ }^{4,5}$, Paula Freire-Pritchett ${ }^{2,6}$, Peter J. Rugg-Gunn (1) ${ }^{7}$, \\ Mikhail Spivakov (1) ${ }^{2}$, Peter Fraser (10) ${ }^{2,8} \&$ Bernard D. Keavney (1) ${ }^{1}$
}

Correction to: Nature Communications https://doi.org/10.1038/s41467-018-04931-0; published online 28 June 2018

In the original version of the Article, the gene symbol for tissue factor pathway inhibitor was inadvertently given as 'TFP1' instead of 'TFPI'. This has now been corrected in both the PDF and HTML versions of the Article.

Published online: 12 November 2018 \begin{abstract}
reproduction in any medium or format, as long as you give appropriate credit to the original author(s) and the source, provide a link to the Creative Commons license, and indicate if changes were made. The images or other third party material in this article are included in the article's Creative Commons license, unless indicated otherwise in a credit line to the material. If material is not included in the article's Creative Commons license and your intended use is not permitted by statutory regulation or exceeds the permitted use, you will need to obtain permission directly from the copyright holder. To view a copy of this license, visit http://creativecommons.org/licenses/by/4.0/.
\end{abstract}

(c) (i) Open Access This article is licensed under a Creative Commons Attribution 4.0 International License, which permits use, sharing, adaptation, distribution and

(C) The Author(s) 2018

\footnotetext{
${ }^{1}$ Division of Cardiovascular Sciences, The University of Manchester, Manchester M13 9PT, UK. ${ }^{2}$ Nuclear Dynamics Programme, The Babraham Institute, Cambridge CB22 3AT, UK. ${ }^{3}$ Josep Carreras Leukaemia Research Institute, Campus ICO-Germans Trias I Pujol, Badalona, 08916 Barcelona, Spain. ${ }^{4}$ MRC Biostatistics Unit, University of Cambridge, Cambridge CB2 OSR, UK. ${ }^{5}$ Department of Medicine, University of Cambridge, Cambridge CB2 OQQ, UK. ${ }^{6}$ Division of Cell Biology, Medical Research Council Laboratory of Molecular Biology, Cambridge CB2 OQH, UK. ${ }^{7}$ Epigenetics Programme, The Babraham Institute, Cambridge CB22 3AT, UK. ${ }^{8}$ Department of Biological Science, Florida State University, Tallahassee 32306 FL, USA. Correspondence and requests for materials should be addressed to M.-K.C. (email: munkit.choy@manchester.ac.uk) or to P.F. (email: pfraser@bio.fsu.edu) or to B.D.K. (email: bernard.keavney@manchester.ac.uk)
} 